\title{
A temperature response function for modeling leaf growth and development of the African violet (Saintpaulia ionantha Wendl.)
}

\author{
Função de resposta à temperatura para modelar o crescimento e desenvolvimento folhar da \\ violeta africana (Saintpaulia ionantha Wendl.)
}

\author{
Nereu Augusto Streck ${ }^{1}$
}

\begin{abstract}
Response functions used in crop simulation models are usually different for different physiological processes and cultivars, resulting in many unknown coefficients in the response functions. This is the case of African violet (Saintpaulia ionantha Wendl.), where a generalized temperature response for leaf growth and development has not been developed yet. The objective of this study was to develop a generalized nonlinear temperature response function for leaf appearance rate and leaf elongation rate in African violet. The nonlinear function has three coefficients, which are the cardinal temperatures (minimum, optimum, and maximum temperatures). These coefficients were defined as 10,24 , and $33^{\circ} \mathrm{C}$, based on the cardinal temperatures of other tropical species. Data of temperature response of leaf appearance rate and leaf elongation rate in African violet, cultivar Utah, at different light levels, which are from published research, were used as independent data for evaluating the performance of the nonlinear temperature response function. The results showed that a generalized nonlinear response function can be used to describe the temperature response of leaf growth and development in African violet. These results imply that a reduction in the number of input data required in African violet simulation models is possible.
\end{abstract}

Key words: temperature, model, leaf growth, leaf development, African violet.

\section{RESUMO}

Funções de resposta usadas em modelos de simulação de culturas freqüentemente são diferentes para diferentes processos fisiológicos e cultivares, fazendo com que muitos coeficientes das funções de respostas sejam desconhecidos. Este é o caso da violeta africana (Saintpaulia ionantha Wendl.), em que uma função geral de resposta à temperatura para o crescimento e desenvolvimento folhar ainda não foi desenvolvida. O objetivo deste trabalho foi desenvolver uma função geral de resposta não linear da taxa de aparecimento de folhas e da taxa de elongação folhar à temperatura para violeta africana. A função não linear tem três coeficientes, que são as temperaturas cardeais (temperaturas mínima, ótima e máxima). Estes coeficientes foram definidos como 10,24 e $33^{\circ} \mathrm{C}$, com base nas temperaturas cardinais de outras espécies tropicais. Dados independentes da taxa de aparecimento de folhas e taxa de elongação folhar em violeta africana (cultivar Utah), cultivada em diferentes temperaturas e níveis de densidade de fluxo de radiação fotossinteticamente ativa, publicados na literatura, foram usados para avaliar a função de resposta proposta. Os resultados mostraram a possibilidade do uso de uma mesma função matemática para descrever a resposta do crescimento e desenvolvimento folhar à temperatura em violeta africana. Estes resultados indicam que é possivel reduzir o número de coeficientes em modelos de simulação para esta espécie vegetal.

Palavras-chave: temperatura, modelo, crescimento folhar, desenvolvimento folhar, violeta africana.

\section{INTRODUCTION}

The African violet or saintpaulia (Saintpaulia ionantha Wendl.) is an extremely popular pot-grown flower worldwide. Brazil is a major market of African violet, with $70-80 \%$ of the production concentrated in the State of São Paulo (AMBROZEVICIUS, 2002). During the period 19921999, about 125 million pots with African violet were sold only in the Veiling-Holambra market, Holambra, SP(MOTOS, 2000). During 1998, 2,297 boxes (34,455 pots) per day were sold in the CEAGESP/SP (AMBROZEVICIUS, 2002). Another major market is the USA, where about 230 million pots with African violet were sold during the period 1991-2000 (USDA, 2002).

African violet is native of the tropical forest areas of East Africa (Kenya and Tanzania)

${ }^{1}$ Engenheiro Agrônomo, PhD., Professor Adjunto, Departamento de Fitotecnia, Centro de Ciências Rurais, Universidade Federal de Santa Maria, 97105-900, Santa Maria, RS, Brasil. E-mail: nstreck1@smail.ufsm.br. 
(JOHANSSON, 1978). African violet plants have a rosette growth habit and the meristem is typically less than $3 \mathrm{~cm}$ above the soil surface (FAUST \& HEINS, 1993). Flowers develop from the axil of leaves when environmental conditions are appropriate. In their natural habitat, African violets grow in an environment of high relative air humidity (70-90\%), moderate air temperatures $\left(20-25^{\circ} \mathrm{C}\right)$, and low solar radiation or partial shade $\left(100-200 \mu \mathrm{mol} \mathrm{m}{ }^{-2} \mathrm{~s}^{-1}\right.$ PPFD=photosynthetic photon flux density) (HEINL, 1960; JOHANSSON, 1978; FREE, 1979; KIMMINS, 1980; STROMME, 1985). African violet is a day-neutral plant (HILDRUM \& KRISTOFFERSEN, 1969).

Commercially, pot-grown flower plants, including African violet, are produced for specific marked dates; therefore, prediction of flowering is an important part of any enterprise with these species (FAUST \& HEINS, 1994). Crop developmental models can assist growers in planning flowering time and transportation of the products to the marketplace. A developmental model is also an important part of any crop simulation model, because plant growth is largely related to photosynthesis whereas the partitioning of assimilates to different organs is dependent upon plant developmental stage (PENNING de VRIES et al., 1989; GOUDRIAN \& VAN LAR, 1994). Crop simulation models offer a conceptual framework for the organization of research as well as are valuable application tools for yield forecast, policy analysis, decision-making activities, crop management practices, and selection of appropriate cultivars in breeding programs. Horticulture is characterized by a high diversity of cultivation systems, and fruit, vegetable, flower and ornamental species, but so far only a few of them have been modeled (GARY et al., 1998).

Research with African violets is not abundant as with other flowers. There is a lack of knowledge about some key processes that affect flowering in African violet such as the mechanism that induces flower initiation (because it is a day-neutral species with respect to flower initiation and development) and why not all leaf axils produce an inflorescence (FAUST \& HEINS, 1994). Therefore, and not surprisingly, models to simulate growth and development of African violet are scarce. In a literature search done in July 2002 involving several database engines (CAB, AGRICOLA, and UNCOVER), the developmental model by FAUST \& HEINS (1994) was the only African violet model found. This model uses what is currently known about the physiology of African violet, and the cycle of the crop is divided in two developmental phases: from transplanting to visible bud and from visible bud to open flower. In the FAUST \& HEINS (1994) model, it is assumed that transplanting in commercial crops occurs at the stage of 8-10 leaves and before transplanting there is no flower initiation as plants are in small pots and at high plant density in the nursery (the assumption here is that high competition for light and nutrients inhibits flower initiation). During the phase from transplanting to visible bud, PPFD and temperature are the environmental factors that control development and during the phase from visible bud to open flower only temperature affects development.

In the FAUST \& HEINS (1994) model, the appearance of the visible bud in each leaf axil is related to the growth of the subtending leaf blade. Therefore, during the phase from transplanting to visible bud, the leaf appearance rate (LAR) and the leaf elongation rate (LER) are calculated. Both LAR and LER are affected primarily by temperature and PPFD. The temperature responses of LAR and LER are modeled by a nonlinear function with three coefficients, namely the cardinal temperatures for development, i.e. the minimum temperature ( $\mathrm{T}$ ), the optimum temperature $\left(\mathrm{T}_{\mathrm{opt}}\right)$, and the maximum temperature $\left(\mathrm{T}_{\mathrm{max}}\right)$, which are different for LAR and LER.

The temperature response of LAR and LER approach in the FAUST \& HEINS (1994) model has at least two disadvantages. One disadvantage is that the $\mathrm{T}_{\mathrm{opt}}$ for LAR is assumed to be dependent on PPFD. This assumption is weakly supported by the experimental data presented by FAUST \& HEINS (1993). Furthermore, this assumption increases the number of input data necessary in crop simulation models. Generalized temperature response functions, which decrease the number of coefficients in simulation models, have been proposed for several field and horticultural crops (e.g. JAME et al., 1998, 1999; YANT AND HUNT, 1999a,b; STRECK, 2002a,b), but not for African violet.

Another disadvantage of the (FAUST \& HEINS, 1994) model is that the cardinal temperatures for LAR and LER are different. For LAR, the $T_{\min }=8^{\circ} \mathrm{C}$, $\mathrm{T}_{\text {opt }}$ is dependent on PPFD, and $\mathrm{T}_{\max }=30.8^{\circ} \mathrm{C}$ (FAUST $\&$ HEINS, 1993), and for LER, $\mathrm{T}_{\min }=13.8^{\circ} \mathrm{C}, \mathrm{T}_{\mathrm{opt}}=24^{\circ} \mathrm{C}$, and $\mathrm{T}_{\max }=29^{\circ} \mathrm{C}$ (FAUST \& HEINS, 1994). Whereas there is no doubt that LAR and LER are different processes (development and growth, respectively), it is also true that, this is a disadvantage as one needs to know two sets of cardinal temperatures, which increases the number of input data. Attempts have been made to describe different plant processes with the same response function, thus reducing the number of coefficients for models, while maintaining the 
biological meaning of the response functions. Such an approach makes crop models friendlier and easier to operate while maintaining their capability of describing major features of the system being modeled. An example is STRECK (2003), who successfully described the temperature response of several growth and developmental parameters in kiwifruit [Actinidia deliciosa (A. Chev.) C. F. Liang \& A. R. Ferguson] with the same response function. In determining the cardinal temperatures, STRECK (2003) used a more mechanistic approach (cardinal temperatures were defined based on independent data from experiments with other species and/or cultivars), which increases the chance of the model to perform well in a wider range of environmental conditions, than the empirical statistical fitting approach used by FAUST \& HEINS $(1993,1994)$, which results in coefficients that may not work in all situations. These disadvantages of the FAUST \& HEINS (1994) model provide a rationale for further improvement of the LAR and LER models in African violet.

The objective of this study was to develop a generalized nonlinear temperature response function for leaf appearance rate and leaf elongation rate in African violet that has coefficients with biological meaning.

\section{MATERIAL AND METHODS}

A typical biological response to temperature from $T_{\min }$ to $T_{\text {opt }}$ follows a logistic curve (SHAYKEWICH, 1995). The response increases slowly as temperature increases from $\mathrm{T}_{\min }$, it increases in a linear fashion at intermediate temperatures, and the rate of increase decreases as temperature approaches $\mathrm{T}_{\text {opt }}$, where the response is at a maximal. At temperatures above $\mathrm{T}_{\mathrm{opt}}$, the response decreases and eventually ceases at $\mathrm{T}_{\max }$. There are several functions that can describe the temperature response of biological processes (LANDSBERG, 1977). The beta function used by WANG \& ENGEL (1998) to describe the response of development to temperature in wheat (Triticum aestivum L.), by STRECK (2002b) to describe the response of node appearance rate in muskmelon (Cucumis melo L.), and by STRECK (2003) to describe the temperature response of several growth and developmental parameters in kiwifruit, was used in this study to describe the temperature response of leaf appearance rate (LAR) and leaf elongation rate (LER) in African violet. The temperature function [ $\mathrm{f}(\mathrm{T})]$ varies from 0 to 1 and is defined as:

$\mathrm{f}(\mathrm{T})=\left[2\left(\mathrm{~T}-\mathrm{T}_{\min }\right)^{\alpha}\left(\mathrm{T}_{\mathrm{opt}}-\mathrm{T}_{\min }\right)^{\alpha}-\left(\mathrm{T}-\mathrm{T}_{\min }\right)^{2 \alpha}\right] /\left(\mathrm{T}_{\mathrm{opt}}-\mathrm{T}_{\min }\right)^{2 \alpha}$

for $\mathrm{T}_{\min } \leq \mathrm{T} \leq \mathrm{T}_{\max }$
$\mathrm{f}(\mathrm{T})=0$

for $\mathrm{T}<\mathrm{T}_{\min }$ or $\mathrm{T}>\mathrm{T}_{\max }$

$\alpha=\ln 2 / \ln \left[\left(\mathrm{T}_{\max }-\mathrm{T}_{\min }\right) /\left(\mathrm{T}_{\mathrm{opt}}-\mathrm{T}_{\min }\right)\right]$

where $T_{\min }, T_{\text {opt }}$, and $T_{\max }$ are the cardinal temperatures. Equation 1 is a flexible curve and, by changing the cardinal temperatures, it can attain several shapes. The temperature response of some biological processes using equation 1 is represented in figure 1 . The vernalization response of winter wheat has cardinal temperatures of $-1,5$, and $16^{\circ} \mathrm{C}$ (PORTER \& GAWITH, 1999). The response of seedling growth rate in maize (Zea mays L.) has cardinal temperatures of 0, 32, and $43^{\circ} \mathrm{C}$ (YAN \& HUNT, 1999a).

In defining the cardinal temperatures for LAR and LER in African violet, it was assumed that $\mathrm{T}_{\text {min }}$ is $10^{\circ} \mathrm{C}$ (HEINL, 1960; FREE, 1979), $\mathrm{T}_{\text {opt }}$ is $24^{\circ} \mathrm{C}$ (HEINL, 1960; FREE, 1979; KIMMINS, 1980; STROMME, 1985), and $\mathrm{T}_{\max }$ is $33^{\circ} \mathrm{C}$ (HILDRUM \& KRISTOFFERSEN, 1969; STROMME, 1985), which are similar to cardinal temperatures for other tropical species (PENNING DE VRIES et al., 1989; HODGES, 1991), including gloxinias [Siningia speciosa (Lodd.) Hiern.], a species classified in the same botanical family (GESNERIACEAE) and native of tropical humid areas of Brazil where environmental conditions are similar to the environmental conditions of tropical East Africa (KIMMINS, 1980; STROME, 1985). Therefore, the function used to describe the temperature response of LAR and LER in African violet with the above cardinal temperatures is:

$\mathrm{f}(\mathrm{T})=\left[2(\mathrm{~T}-10)^{\alpha}(14)^{\alpha}-(\mathrm{T}-10)^{2 \alpha}\right] /(14)^{2 \alpha}$

for $\mathrm{T}_{\min } \leq \mathrm{T} \leq \mathrm{T}_{\max }$

$\mathrm{f}(\mathrm{T})=0$

for $\mathrm{T}<\mathrm{T}_{\min }$ or $\mathrm{T}>\mathrm{T}_{\max }$

with $\alpha=1.3962$. The response curve generated with equation 3 is plotted in figure 1 .

In order to test the performance of equation 3, independent data of LAR (leaves day ${ }^{-1}$ ) and LER $\left(\mathrm{mm} \mathrm{day}^{-1}\right)$ in African violet reported in the literature were used. The LAR data are from an experiment in controlled-environment rooms at five temperatures (14, $18,22,26$, and $30^{\circ} \mathrm{C}$ ) and four photosynthetic photon flux densities $\left(\mathrm{PPFD}=1 \mathrm{~mol} \mathrm{~m}^{-2} \mathrm{day}^{-1}, \mathrm{PPFD}=4 \mathrm{~mol} \mathrm{~m}\right.$ ${ }^{2} \mathrm{day}^{-1}, \mathrm{PPFD}=7 \mathrm{~mol} \mathrm{~m}^{-2} \mathrm{day}^{-1}$, and PPFD $=10 \mathrm{~mol} \mathrm{~m}^{-2}$ day $^{-1}$ ) reported in FAUST \& HEINS (1993). The LER data are from an experiment in controlled-environment rooms at four temperatures $\left(14,18,22\right.$, and $\left.26^{\circ} \mathrm{C}\right)$ reported in FAUST \& HEINS (1994). The cultivar used in both studies was 'Utah'. Data of LAR and LER were presented in figures in the original papers [Figure 2 in FAUST \& HEINS (1993), and figure 6 in FAUST \& HEINS (1994)]. Data from these figures were extracted by enlarging the diagram and estimating the values of 
LAR and LER, in an attempt to minimize random errors of interpolation. In all cases, LAR and LER data were normalized to vary from 0 to 1 by dividing each value by the maximum value, which was either at 22 or $26^{\circ} \mathrm{C}$.

The observed normalized LAR and LER data were compared to the $\mathrm{f}(\mathrm{T})$ predicted by equation 3 in each temperature and PPFD level. The statistic used for evaluating the model performance was the root mean square error (RMSE), calculated as (JANSSEN \& HEUBERGER, 1995):

$\operatorname{RMSE}=\left[\Sigma\left(\mathrm{P}_{\mathrm{i}}-\mathrm{O}_{\mathrm{i}}\right)^{2} / \mathrm{N}\right]^{0.5}$

where $\mathrm{P}_{\mathrm{i}}=$ predicted data, $\mathrm{O}_{\mathrm{i}}=$ observed data, $\mathrm{N}=$ number of observations, and $\mathrm{i}=1 \ldots \mathrm{N}$. The RMSE expresses the spread in $\mathrm{P}_{\mathrm{i}}-\mathrm{O}_{\mathrm{i}}$ and has the same units as the predicted and the observed data (in this study it is unitless). The lower the RMSE the better the prediction.

\section{RESULTSAND DISCUSSION}

The observed normalized data of LAR and LER of the African violet, cultivar Utah, grown at different temperature and photosynthetic photon flux densities levels, and the temperature response curve predicted by equation 3 are presented in figure 2 . The observed data show a maximum response in the range of $22-26^{\circ} \mathrm{C}$ and a decrease when temperature departs from $\mathrm{T}_{\mathrm{opt}}$. A linear response occurs only at intermediate temperatures $\left(16-22^{\circ} \mathrm{C}\right)$. Close to the optimum temperature $\left(24^{\circ} \mathrm{C}\right)$, the response is nonlinear. This trend was captured by the beta function (equation 3), which had a good performance over the entire range of observed data $(\mathrm{RMSE}=0.074)$. Also, the observed data, as they were normalized with respect to their maximum, all fall into a similar pattern of response to temperature, suggesting a general type of response for both growth and development of leaves (i.e., LER and LAR).

Virtually all the metabolic processes in living organisms are temperature-dependent. As a consequence, temperature affects almost all aspects of plant growth and development. The first quantitative study of plant-temperature relationship is attributed to René A. F. de Réaumur around 1730 (RÉAUMUR, 1735). Since then, the concept of heat units, or thermal time, has been widely used to describe the temperature response in plants and insects (see WANG, 1960; ARNOLD, 1960; PRUESS, 1983 for detailed reviews). The appearance of leaves is a result of processes such as leaf initiation, and cell division and growth, whereas leaf area expansion is dependent

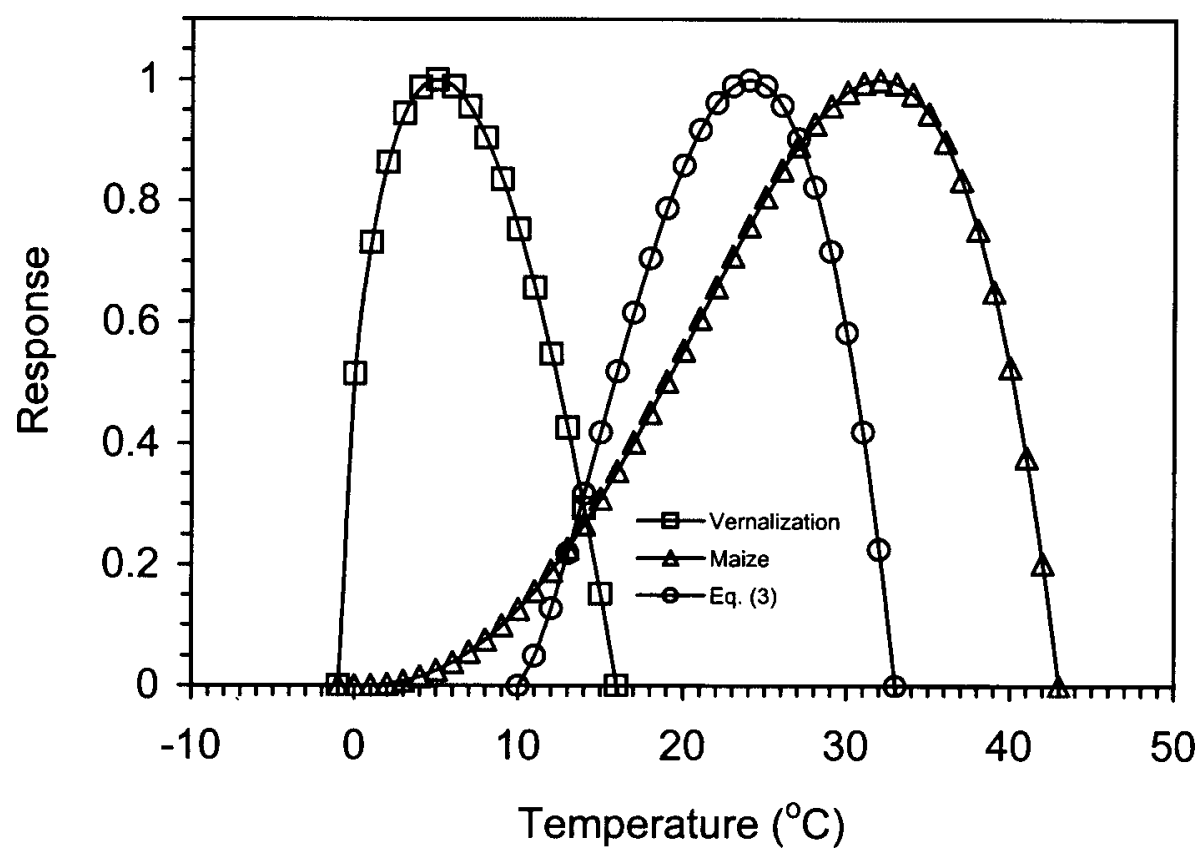

Figure 1 - The beta function (equation 1) describing the temperature response of three plant processes: the vernalization response of winter wheat (Triticum aestivum L.) with $\mathrm{T}_{\min }=-1^{\circ} \mathrm{C}, \mathrm{T}_{\mathrm{op}}=5^{\circ} \mathrm{C}$, and $\mathrm{T}_{\max }=16^{\circ} \mathrm{C}$ (PORTER \& GAWITH, 1999); the response of seedling growth rate in maize (Zea mays L.) with $\mathrm{T}_{\min }=0^{\circ} \mathrm{C}, \mathrm{T}_{\mathrm{opt}}=32^{\circ} \mathrm{C}$, and $\mathrm{T}_{\max }=43^{\circ} \mathrm{C}$ (YAN \& HUNT, 1999a); and the leaf appearance rate and leaf elongation rate response in African violet (Saintpaulia ionantha Wendl. ) with $\mathrm{T}_{\min }=10^{\circ} \mathrm{C}, \mathrm{T}_{\mathrm{opt}}=24^{\circ} \mathrm{C}$, and $\mathrm{T}_{\max }=33^{\circ} \mathrm{C}$ [Eq. (3)]. 


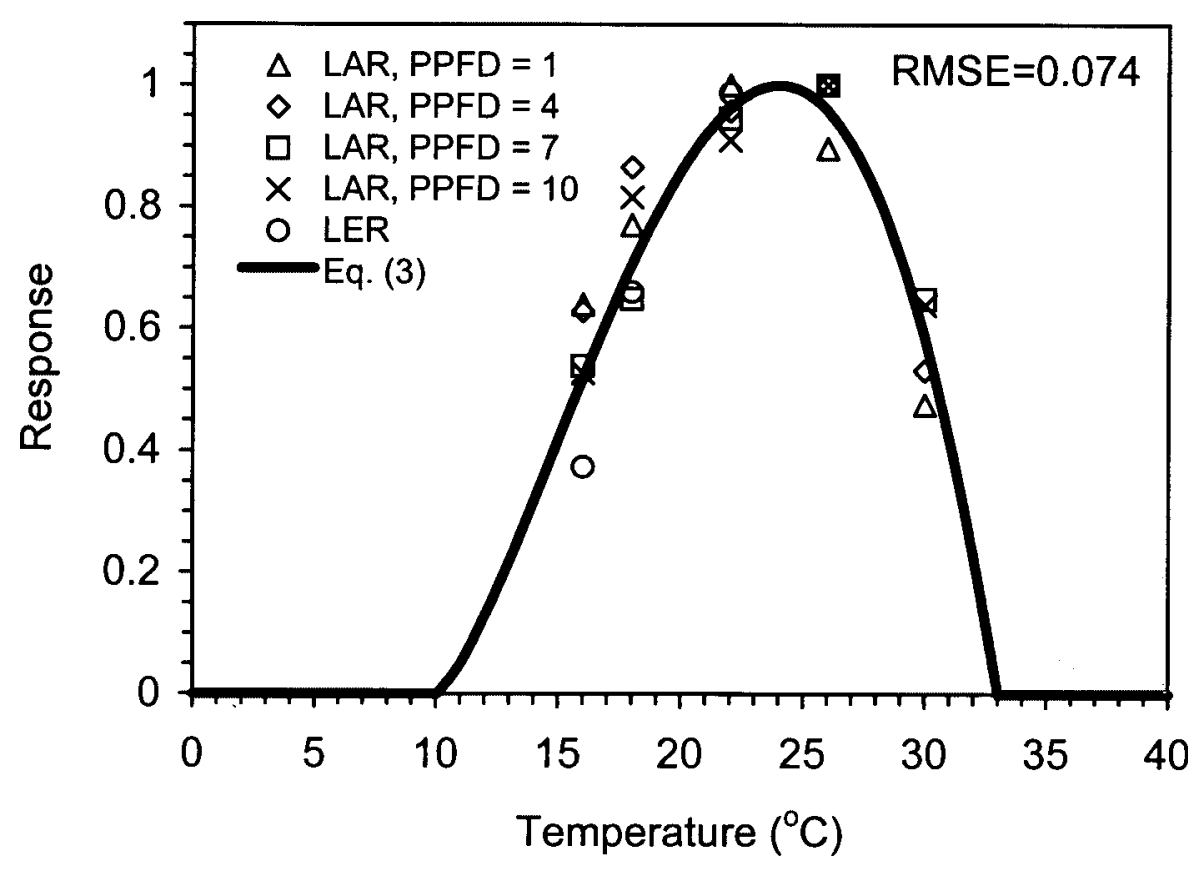

Figure 2 - The performance of the beta function [Eq. (3)] in describing the temperature response of leaf appearance rate (LAR) and leaf elongation rate (LER) of African violet, cultivar Utah. Observed LAR and LER data are from experiments in controlledenvironment rooms reported in FAUST \& HEINS (1993) and FAUST \& HEINS (1994), respectively. Observed LAR data are for plants grown at four photosynthetic photon flux densities (PPFD): PPFD $=1$ is at $1 \mathrm{~mol} \mathrm{~m}^{-2}$ day $^{-1}, \mathrm{PPFD}=4$ is at $4 \mathrm{~mol} \mathrm{~m}^{-2}$ day $^{-1}$, $\mathrm{PPFD}=7$ is at $7 \mathrm{~mol} \mathrm{~m}^{-2}$ day $^{-1}$, and PPFD $=10$ is at $10 \mathrm{~mol} \mathrm{~m}^{-2}$ day $^{-1}$.

upon cell division and growth (KIRBY, 1990; HAY \& KIRBY, 1991). All these processes are directly or indirectly affected by temperature (JONES, 1992). For instance, cell growth is dependent on net photosynthesis $(\mathrm{Pn})$, a process which is sensitive to temperature, with both physical and biochemical limitations playing a role to decrease Pn at sub- and supra-optimal temperatures (PENNING de VRIES et al., 1989; JONES, 1992). An increase in Pn as temperature increases from $T_{\min }$ to $T_{\text {opt }}$ is a result of an increase in either one or both stomatal and mesophyll conductance to $\mathrm{CO}_{2}$, and an increase in the activity of the enzyme ribulose 1,5-bisphosphate carboxylase (Rubisco) with temperature (LUDLOW \& WILSON, 1971; JONES, 1992). A decline in Pn as temperature increases from $T_{\text {opt }}$ to $T_{\text {max }}$ is associated with a decrease in either one or both stomatal and mesophyll conductance to $\mathrm{CO}_{2}$ with temperature (LUDLOW \& WILSON, 1971), a rapid increase in dark respiration (and in $\mathrm{C}_{3}$ plants, like African violet, photorespiration as well) with temperature (JACKSON \& VOLK, 1970), and an inactivation of Rubisco at supra-optimal temperatures (JONES, 1992). Another reason why Pn decreases at supra-optimal temperatures in $\mathrm{C}_{3}$ plants is that the solubility of $\mathrm{CO}_{2}$ decreases relatively faster than the solubility of $\mathrm{O}_{2}$, causing an unbalance between carboxylase and oxigenase activities of Rubisco, which leads to an $\mathrm{O}_{2}$ inhibition at the carboxylation site that decreases Pn (LAING et al., 1974; EHLERINGER \& BJÖRKMAN, 1977; KU \& EDUARDS, 1977).

Response functions used in crop simulation models are usually different for different processes (PENNING de VRIES, 1989). This is often a problem, because the coefficients of the functions are unknown for many cultivars and species. The use of Occam's Razor in crop modeling is encouraged (SINCLAIR \& MUCHOW, 1999), i.e., the simplest theory is preferred to more complex ones or explanations of phenomena should be in terms of known quantities. Therefore, the search for generalized response functions is a major goal in crop modeling.

As shown in this study, the response of leaf growth and development to temperature in African violet can be described by a generalized nonlinear function. These results agree with STRECK (2003), who was also able to describe the temperature response of several growth and developmental

Ciência Rural, v. 34, n. 1, jan-fev, 2004. 
parameters in kiwifruit with the same response function. Several reasons contribute to adopt equation 3 as a generalized temperature function for LAR and LER in African violet. Firstly, the coefficients (the cardinal temperatures) have biological meaning as they represent good approximations of African violets natural habitat in the tropical region of East Africa, where the air temperature varies between 18 and $33^{\circ} \mathrm{C}$ throughout the year (JOHANSSON, 1978). Secondly, equation 3 is a robust and general function, as the cardinal temperatures $\left(\mathrm{T}_{\min }, \mathrm{T}_{\mathrm{opt}}\right.$, and $\left.\mathrm{T}_{\max }\right)$ were derived from independent studies and based on different tropical species (e.g. gloxinias). Thirdly, equation 3 was a good predictor of the temperature response of LAR at different PPFD levels, which is an improvement over the existing approach where $\mathrm{T}_{\mathrm{opt}}$ is a function of PPFD (FAUST \& HEINS, 1993). Fourthly, the fact that the temperature response of two different plant physiological processes, LAR (development) and LER (growth) was well described by the same response function is also an improvement over the existing approach, which assumes that cardinal temperatures are different for these two processes (FAUST \& HEINS, 1994). Fifthly, the function (equation 3 ) describes what is currently accepted in terms of temperature response of biological systems (SHAYKEWICH, 1995). At temperatures close to $T_{\min }$, the response is close to 0 , the response increases in a linear fashion at intermediate temperatures, the response reaches a maximum when temperature approaches $\mathrm{T}_{\mathrm{opt}}$, and the response decreases afterwards down to 0 at $T_{\max }$.

The values of $T_{\min }$ and $T_{\max }$ for LAR and LER in African violet assumed in this study differ from the values estimated with statistical fitting procedures by FAUST \& HEINS $(1993,1994) . \mathrm{A} \mathrm{T}_{\min }$ of $10^{\circ} \mathrm{C}$ for both LAR and LER, assumed in this study, rather than $8^{\circ} \mathrm{C}$ for LAR and $13.8^{\circ} \mathrm{C}$ for LER (FAUST \& HEINS, 1993, 1994), is more realistic for African violet because FAUST \& HEINS (1994) stated that "we have observed that injury of African violet occurs between 10 and $12.5^{\circ} \mathrm{C}$ ". FAUST \& HEINS (1993) estimated that $\mathrm{T}_{\max }$ for LAR is $30.8^{\circ} \mathrm{C}$, which is unrealistically too low as the observed LAR response at $30^{\circ} \mathrm{C}$ was between 0.45 and 0.65 (Figure 2). Likewise, FAUST \& HEINS (1994) estimated a $\mathrm{T}_{\max }$ for LER of $29^{\circ} \mathrm{C}$, which may also be unrealistic and the result of an artifact of the statistical fitting procedure used by the authors, as the highest temperature treatment was only $26^{\circ} \mathrm{C}$, at which the observed LER response was maximal (1.00). Therefore, a $T_{\max }=33^{\circ} \mathrm{C}$ for both LAR and LER, as assumed in this study, is probably more realistic from a biological point of view. The $\mathrm{T}_{\text {opt }}$ for LAR was estimated by FAUST \& HEINS (1993) as varying between 22.6 and $25.5^{\circ} \mathrm{C}$ whereas for LER it was $24^{\circ} \mathrm{C}$ (FAUST \& HEINS, 1994). These values agree with the $T_{\text {opt }}$ assumed in this study for both LAR and LER $\left(24^{\circ} \mathrm{C}\right)$.

Crop simulation models are incomplete tools and errors in the predictions are still quite frequent, including African violet models. For instance, FAUST \& HEINS (1994) reported that the predicted time to visible bud appearance in African violets was consistently longer than the observed time, and predictions were often 10 days off. The responses of some basic plant processes to environmental factors in African violet are still not well understood and, consequently, poorly described in crop simulation models. It may be that the LAR and LER response to temperature is one among them. The fact that the nonlinear response function presented in this paper was a good predictor of the temperature response of leaf growth and development under different PPFD levels suggests that the performance of African violet models can be improved.

\section{CONCLUSION}

A generalized nonlinear response function, with cardinal temperatures of 10,24 , and $33^{\circ} \mathrm{C}$, can be used to describe the temperature response of leaf growth and development in African violet. This conclusion implies that a reduction in the number of input data required in African violet simulation models is possible.

\section{ACKNOWLEDGMENTS}

The author is grateful to the Conselho Nacional de Desenvolvimento Científico e Tecnológico ( $\mathrm{CNPq}$ ), of the Ministry for Science and Technology of Brazil, for financial support during this study.

\section{REFERENCES}

AMBROZEVICIUS, N. Mercado de flores da CEAGESP/ SP. Campinas : CEASA, 2002. 37p. Capturado em 16 outubro 2002. Online. Available at http://www.ceasacampinas.com.br/ depo.doc.

ARNOLD, C.Y. Maximum-minimum temperatures as a basis for computing heat units. Proceedings of the American Society for Horticultural Science, Boston, v.76, n.1, p.682-692, 1960 .

EHLERINGER, J.; BJÖRKMAN, O. Quantum yields for $\mathrm{CO}_{2}$ uptake in $\mathrm{C}_{3}$ and $\mathrm{C}_{4}$ plants. Plant Physiology, Baltimore, v.59, n.1, p.86-90, 1977.

FAUST, J.E.; HEINS, R.D. Modeling leaf development of the African violet (Saintpaulia ionantha Wendl.). Journal of the American Society for 
Horticultural Science, Alexandria, v.118, n.6, p.747-751, 1993.

FAUST, J.E.; HEINS, R.D. Modeling inflorescence development of the African violet (Saintpaulia ionantha Wendl.). Journal of the American Society for Horticultural Science, Alexandria, v.119, n.4, p.727-734, 1994.

FREE, M. Growing conditions. In: All about African violets: the complete guide to success with saintpaulias. Garden City : Doubleday, 1979. Cap. 4, p.3650 .

GARY, C.; JONES, J.W.; TCHAMITCHIAN, M. Crop modeling in horticulture: state of the art. Scientia Horticulturae, Amsterdam, v.74, n.1, p.3-20, 1998.

GOUDRIAN, J.; VAN LAAR, H.H. Modeling potential crop growth processes. Dordrecht : Kluwer, 1994. 238p.

HAY, R.K.M.; KIRBY, E.J.M. Convergence and synchrony a review of the coordination of development in wheat. Australian Journal of Agricultural Research, Melbourne, v.42, n.5, p.661-700, 1991.

HEINL, L.J. How to grow and bloom African violets at home. 3.ed. Toledo : Green Thumb, 1960. 32p.

HILDRUM, H.; KRISTOFFERSEN, T. The effect of temperature and light intensity on flowering in Saintpaulia ionantha Wendl. Acta Horticulture, The Hague, v.14, n.1, p.249-255, 1969.

HODGES, T. Predicting crop phenology. Boca Raton : CRC, 1991. 233p.

JACKSON, W.A.; VOLK, R.J. Photorespiration. Annual Review of Plant Physiology, Palo Alto, v.21, n.1, p.385432, 1970.

JAME, Y.M.; CUTFORTH, H.W.; RITCHIE, J.T Temperature response function for leaf appearance rate in wheat and corn. Canadian Journal of Plant Science, Ottawa, v.79, n.1, p.1-10, 1999.

JAME, Y.M.; CUTFORTH, H.W.; RITCHIE, J.T. Interaction of temperature and daylength on leaf appearance rate in wheat and barley. Agricultural and Forest Meteorology, Amsterdam, v.92, n.2, p.241-249, 1998.

JANSSEN, P.H.M.; HEUBERGER, P.S.C. Calibration of process-oriented models. Ecological Modelling, Amsterdam, v.83, n.1, p.55-56, 1995.

JOHANSSON, D.R. Saintpaulias in their natural environment with notes on their present status in Tanzania and Kenya. Biological Conservation, London, v.14, n.1, p.45-62, 1978.

JONES, H.G. Plants and microclimate. 2.ed. New York : Cambridge University, 1992. 428p.

KIMMINS, R.K. Gloxinias, African violets, and other Cesneriads. In: LARSON, R.A. Introduction to floriculture. New York : Academic, 1980. Cap.11, p.287-300.

KIRBY, E.J.M. Co-ordination of leaf emergence and leaf and spikelet primordium initiation in wheat. Field Crops Research, Amsterdam, v.25, n.3-4, p.253-264, 1990.

KU, S.B.; EDWARDS, G.E. Oxygen inhibition of photosynthesis. I. Temperature dependence and relation to $\mathrm{O}_{2} / \mathrm{CO}_{2}$ solubility ratio. Plant Physiology, Baltimore, v. 549 n. 5, p. 986-990, 1977.

LAING, W.A.; OGREN, W.L.; HAGEMAN, R.H. Regulation of soybean net photosynthesis $\mathrm{CO}$ fixation by the interaction of $\mathrm{CO}_{2}, \mathrm{O}_{2}$, and ribulose 1,5-diphốsphate carboxylase. Plant Physiology, Baltimore, v.54, n.5, p.678-685, 1974.

LANDSBERG, J.J. Some useful equations for biological studies. Experimental Agriculture, New York, v.13, n.1, p.273286, 1977.

LUDLOW, M.M.; WILSON, G.L. Photosynthesis of tropical pasture plants. I. Illuminance, carbon dioxide concentration, leaf temperature, and leaf-air vapor pressure difference. Australian Journal of Biological Sciences, Melbourne, v.24, n.3, p.449-470, 1971.

MOTOS, J.R. A produção de flores e plantas ornamentais no Brasil e no mundo. Holambra : Flortec - Consultoria e Treinamento, 2000. 8p. Capturado em 27 Junho 2002. Online. Available at http://www.flortec.com.br/artigos/ a_produção_de_flores_e_plantas_o.htm.

PENNING de VRIES, F.W.T. et al. Simulation of ecophysiological processes of growth in several annual crops. Wageningen : Pudoc, 1989. 271p.

PORTER, J.R.; GAWITH, M. Temperatures and the growth and development of wheat: a review. European Journal of Agronomy, Amsterdam, v.10, n.1, p.23-36, 1999.

PRUESS, K.P. Day-degree days methods for pest managements. Environmental Entomology, College Park, v.12, n.3, p. 613619, 1983.

RÉAUMUR, R.A.F.de. Observation du thermometer, faites à Paris pendant l'année 1735, compares avec celles qui ont été faites sous la ligne, à l'Isle de France, à Alger et en quelques-unes de nos isles de l'Amérique. Paris : Mémoires de l'Académie des Sciences, 1735. 545p.

SHAYKEWICH, C.F. An appraisal of cereal crop phenology modeling. Canadian Journal of Plant Science, Ottawa, v.75, n.2, p.329-341, 1995.

SINCLAIR, T.R.; MUCHOW, R.C. Occam's Razor, radiation use efficiency and and vapor pressure. Field Crops Research, Amsterdam, v.62, n.2-3, p.239-243, 1999.

STRECK, N.A. Developmental and physiological responses of winter wheat (Triticum aestivum L.) to selected environmental factors. 2002a. 124f. Dissertation (PhD. in Agronomy) - School of Natural Resources Sciences, Institute of Natural Resources Sciences, University of Nebraska, Lincoln.

STRECK, N.A. A generalized nonlinear air temperature response function for node appearance rate in muskmelon (Cucumis melo L.). Revista Brasileira de Agrometeorologia, Santa Maria, v.10, n.1, p.105-111, 2002 b. 
STRECK, N.A. A generalized nonlinear temperature response function for some growth and developmental parameters in kiwifruit (Actinidia deliciosa (A. Chev.) C. F. Liang \& A. R. Ferguson). Ciência Rural, Santa Maria, v.33, n.2, p.255262, 2003

STROMME, E. Gesneriaceae. In: HALEY, H.C. CRC Handbook of flowering. Boca Raton : CRC, 1985. V.3, p.48-52.

USDA (United States Department of Agriculture) Agricultural statistics 2002. Washington : USDA, National Agricultural Statistic Service, 2002. 450p. Capturado em 12 Julho 2002. Online. Available at http://www.usda.gov/nass/pubs/ agstats.htm)
WANG, J.Y. A critique of the heat unit approach to plant response studies. Ecology, Durham, v.41, n.4, p.785-790, 1960.

WANG E.; ENGEL,T. Simulation of phenological development of wheat crops. Agricultural Systems, Amsterdam, v.58, n.1, p.1-24, 1998.

YAN, W.; HUNT, L.A. An equation for modeling the temperature response of plants using only cardinal temperatures. Annals of Botany, London, v.84, n.5, p.607-614, 1999a.

YAN, W.; HUNT, L.A. Reanalysis of vernalization data of wheat and carrot. Annals of Botany, London, v.84, n.5, p.615-619, 1999b. 